\title{
COMPLIANCE TO DRUG USE IN HYPERTENSIVE PATIENTS AND ITS RELATIONSHIP WITH VARIABLES AFFECTING IN THREE CITIES IN INDONESIA
}

\section{MUHAMMAD MUHLIS ${ }^{*}{ }^{*}$, DEWI KARLINA ${ }^{1}$, MERLI NAMITA ${ }^{1}$, LALA MARESTA ${ }^{1}$, YOCIKA ESTI FEROLIA ${ }^{1}$}

\author{
1Faculty of Pharmacy, Universitas Ahmad Dahlan, Yogyakarta, Indonesia
}

*Email: muhlis3@yahoo.co.id

Received: 31 Aug 2020, Revised and Accepted: 10 Oct 2020

\section{ABSTRACT}

Objective: Patient noncompliance in taking medication is the problem in hypertension therapy. This study aims to describe the compliance to drug use in hypertensive patients in Bengkulu, Banjarmasin, and Yogyakarta, Indonesia.

Methods: This study is an observational study using a questionnaire, with a total sample size of 300 . Data are analyzed by using bivariate analysis with the chi-square method to see if there is a relationship between compliance and predetermined variables.

Results: The study in three cities showed that there were 0 patients (0\%) Low compliance and non-compliance category patients; the compliance category was $91 \%, 10 \%, 8 \%$, respectively. High compliance categories were $9 \%, 90 \%, 92 \%$. Chi-square test shows that compliance has a significant relationship $\left({ }^{*} \mathrm{P}<0.05\right)$ in the three cities on the variable "treatment motivation", other variables that show a significant relationship in the city of Yogyakarta are "drug side effects", "role of health workers", "social support", in Bengkulu is "Therapeutic beliefs", in Banjarmasin is" Knowledge of therapeutic effects".

Conclusion: All hypertensive patients have good compliance; compliance is significantly associated in all three cities on the variable "treatment motivation."

Keywords: Compliance, Hypertension, Influencing factors

(C) 2021 The Authors. Published by Innovare Academic Sciences Pvt Ltd. This is an open access articleunder the CC BY license (http://creativecommons.org/licenses/by/4.0/) DOI: http://dx.doi.org/10.22159/ijap.2021.v13s2.11 Journal homepage: https://innovareacademics.in/journals/index.php/ijap

\section{INTRODUCTION}

Hypertension is an extraordinary global problem. It ranks third as the cause of decreased life expectancy and disability [1]. Hypertension is defined as a continuous increase from blood pressure to $140 / 90 \mathrm{mmHg}$ or higher, the risk of hypertension can be increased gradually; gradually concomitant increase in systolic and diastolic blood pressure [2]. If it is not handled properly, it can cause complications that are more dangerous for sufferers, including an increased risk of stroke, kidney failure and heart failure [3-5]. The stroke risk is reduced if the initial systolic blood pressure (SBP) is more than $140 \mathrm{~mm} \mathrm{Hg}$ and after receiving therapy, the SBP is achieved less than $140 \mathrm{~mm} \mathrm{Hg}$ [6].

To achieve the goal of hypertension therapy, several strategies are needed in addition to the use of appropriate drugs, such as patient compliance, both compliance in seeing a doctor, compliance in taking medication, compliance to lifestyle and diet, and emotional stability $[7,8]$. The pharmacist's role to achieve the goals of this therapy is to provide pharmaceutical care in the use of drugs so that patients become more obedient in using drugs according to doctor's recommendations [9].

To be able to carry out appropriate pharmaceutical care strategies for hypertensive sufferers, pharmacists must know the level of patient compliance in using drugs so that the level of compliance with patient drug use must be measured in advanced.

\section{MATERIALS AND METHODS}

\section{Ethical approval}

This research has received an Ethical Approval from the Research Ethics Committee of the Ahmad Dahlan University of Indonesia No: 011911109 in December 2019. The research methodology used is observational analytic with a Cross-Sectional approach.

\section{Data collection}

Data collection used is a self-made questionnaire to measure the level of patient compliance with 5 variables (V). V-1 is the compliance variable using drug doses, $\mathrm{V}-2$ is the compliance variable in the frequency of drug use, V-3 compliance variable in time of drug use, V-4 compliance variable in drug use interval, and V-5 compliance variable for the duration of drug use.

The variables affecting compliance used 11 variables including family support, drug side effects, treatment costs, the role of health workers, therapy beliefs, knowledge of the effects of therapy, drug information provision, motivation for treatment, affordability of health services, busy work status, social support.

\section{Data analysis}

The relationship between compliance and variables affecting compliance was analyzed using the chi-square, one-way, with an error rate of $0.05 \%$. There was a statistically significant difference if $* \mathrm{P}<0.05$.

\section{RESULTS AND DISCUSSION}

The questionnaire was tested for the validity of 150 respondents using the Pearson Correlation technique; the validity test shows that each question item has a value of r-Count greater than $r$ - table, so it is concluded that all question items are valid.

Compliance is categorized into four categories, namely: Low compliance, non-compliance, compliance, and very compliance. The results can be seen in table 1 .

Based on table 1, in general, hypertensive patients in the three cities shows none in non-compliance to drug use. It is indicated by a zero value, at the level of non-compliance and low-compliance. Overall patients in three cities are categorized as compliance (100\%).

There is a slight variation in the levels of compliance and highcompliance, in Bengkulu City, the level of compliance is higher than the other two cities. For Yogyakarta City, the level of highcompliance is higher than in the other two cities.

The results of this study are different from the research conducted by Osamor (2011), a study conducted in Southwest Nigeria, it is reported that patients are compliance to taking hypertension drugs only 50.7\% [10], while Mahmoud (2012), reported that the level of 
patient compliance in the city of Medina as much as $15.6 \%$ [11], Chusna (2014) reported the level of compliance of hypertensive patients at dr. Doris Sylvanus Palangkarya, Indonesia as much as
43\% [12], Rahmadani (2018) reported that the level of compliance of hypertensive patients at the public health center in Yogyakarta City, Indonesia is $59.1 \%$ [13].

Table 1: Distribution of compliance overview

\begin{tabular}{|c|c|c|c|c|c|c|c|c|}
\hline \multirow{2}{*}{$\begin{array}{l}\text { Level of } \\
\text { compliance }\end{array}$} & \multirow{2}{*}{$\begin{array}{l}\text { Compliance } \\
\text { score }\end{array}$} & \multicolumn{2}{|l|}{ Bengkulu } & \multicolumn{2}{|l|}{ Banjarmasin } & \multicolumn{2}{|l|}{ Yogyakarta } & \multirow{2}{*}{$\begin{array}{l}\text { Average } \\
\%\end{array}$} \\
\hline & & Number of patients (N) & $\%$ & $\begin{array}{l}\text { Number of } \\
\text { patients }(\mathrm{N})\end{array}$ & $\%$ & Number of patients $(\mathrm{N})$ & $\%$ & \\
\hline Low-compliance & $0-4.75$ & 0 & 0 & 0 & 0 & 0 & 0 & 0 \\
\hline non-compliance & $4.75-9.5$ & 0 & 0 & 0 & 0 & 0 & 0 & 0 \\
\hline compliance & $9.5-14.25$ & 16 & 16 & 10 & 10 & 8 & 8 & 11.4 \\
\hline High-compliance & $14.25-19$ & 84 & 84 & 90 & 90 & 92 & 92 & 88.6 \\
\hline
\end{tabular}

From the data obtained by the researcher, the main factor causing the decrease in compliance rate is caused by variable V-4; the compliance variable in the interval of drug use, with the question "Do you always use the drug at the same time every day?". In this question there were $22 \%$ of patients answered "no", it means that $22 \%$ of patients did not take the drug at the same time every day, some patients took the drug in the morning, sometimes at 6 am or 7 am or $8 \mathrm{am}$, for it is important that they drink the medicine every morning. The duration of taking medication from one dose to another has an effect on drug levels in the blood [14], hypertensive drugs such as amlodipine, irbesartan have a $t 1 / 2$ elimination long enough so that the frequency of use is enough once a day [15], this factor causes the difference in the hours taking medicine does not really affect the level of the drug in the blood, unless the distance to taking medicine is too long, for example on the first day it is taken in the morning, and the next day the drug is taken at night.

Table 2: Distribution of respondents according to variables affecting patient compliance

\begin{tabular}{|c|c|c|c|c|c|}
\hline Variabel & Statement & Bengkulu \% & Banjar-masin \% & Yogya-karta \% & Average \% \\
\hline \multirow[t]{2}{*}{ Family support } & $\mathrm{S}$ & 89.8 & 92 & 40 & 73.9 \\
\hline & NS & 10.2 & 8 & 60 & 26.1 \\
\hline \multirow[t]{2}{*}{ Side effects } & NSE & 91.8 & 88 & 91 & 90.3 \\
\hline & SE & 8.2 & 12 & 9 & 9.7 \\
\hline \multirow[t]{2}{*}{ Medical cost/insurance } & UI & 88.8 & 85 & 42 & 71.9 \\
\hline & DUI & 11.2 & 15 & 58 & 28.1 \\
\hline \multirow[t]{2}{*}{ The role of health workers } & high & 92.9 & 89 & 83 & 88.3 \\
\hline & low & 7.1 & 11 & 17 & 11.7 \\
\hline \multirow{2}{*}{ Therapeutic beliefs } & beliefs & 91.8 & 98 & 74 & 87.9 \\
\hline & Not beliefs & 8.2 & 2 & 26 & 12.1 \\
\hline \multirow[t]{2}{*}{ Knowledge level of therapeutic effects } & high & 69.4 & 85 & 80 & 78.1 \\
\hline & low & 30.6 & 15 & 20 & 21.9 \\
\hline \multirow{2}{*}{ Drug information administration } & DI & 92.9 & 93 & 42 & 76.0 \\
\hline & NDI & 7.1 & 7 & 58 & 24.0 \\
\hline \multirow{2}{*}{ Motivation for treatment } & high & 96.9 & 91 & 64 & 84.0 \\
\hline & low & 3.1 & 9 & 36 & 16.0 \\
\hline \multirow[t]{2}{*}{ Affordability of health services } & Aff & 77.6 & 84 & 68 & 76.5 \\
\hline & NA & 22.4 & 16 & 32 & 23.5 \\
\hline \multirow[t]{2}{*}{ Busyness status } & busy & 95.9 & 5 & 30 & 43.6 \\
\hline & not busy & 4.1 & 95 & 70 & 56.4 \\
\hline \multirow{2}{*}{ Social support. } & $\mathrm{S}$ & 85.7 & 95 & 63 & 81.2 \\
\hline & NS & 14.3 & 5 & 37 & 18.8 \\
\hline
\end{tabular}

Note: S: Supported; NS: Not Supported, NSE: no side effects, SE: are side effects; UI: Using insurance; DSU: Don't use insurance; DI: got drug information; NDI: didn't get drug information; Aff: Affordable NA: not affordable

Based on table 2 it can be seen that all the variables affecting patients taking hypertension drugs are influential, only in Yogyakarta City, there are several variables including family support, medical/insurance costs, providing information on drugs that have a lower status effect than the two other cities. This difference can be because the city of Yogyakarta is a large city, its residents live in urban areas, residents in urban areas are usually more independent, have better access to information and have above average income [16].

Table 3: Chi-Square test results, the relationship between the levels of compliance with variables that influence it

\begin{tabular}{|c|c|c|c|c|c|c|c|}
\hline \multirow[t]{2}{*}{ No } & \multirow[t]{2}{*}{ Variabel } & \multicolumn{2}{|c|}{ Bengkulu } & \multicolumn{2}{|c|}{ Banjarmasin } & \multicolumn{2}{|c|}{ Yogyakarta } \\
\hline & & OR & P-value & OR & P-value & OR & P-value \\
\hline 1 & Family support & 1.321 & 0.665 & 3.500 & 0.182 & 0.368 & 0.261 \\
\hline 2 & Side effects & 3.554 & 0.120 & 2.000 & 0.343 & 8.600 & 0.023 \\
\hline 3 & Medical cost/insurance & 1.159 & 1.000 & 2.786 & 0.171 & 0.275 & 0.404 \\
\hline 4 & The role of health workers & 0.844 & 1.000 & 4.393 & 0.078 & 6.007 & 0.027 \\
\hline 5 & therapeutic beliefs & 11.970 & 0.003 & 9.889 & 0.191 & 3.182 & 0.200 \\
\hline 6 & Knowledge level of therapeutic effects & 1.450 & 0.559 & 8.000 & 0.006 & 2.647 & 0.196 \\
\hline 7 & Drug information administration & 0.800 & 1.000 & 1.556 & 0.533 & 0.918 & 1.000 \\
\hline 8 & Motivation for treatment & 0.137 & 0.004 & 6.000 & 0.044 & 5.192 & 0.040 \\
\hline 9 & Affordability of health services & 2.475 & 0.186 & 2.538 & 0.198 & 3.310 & 0.380 \\
\hline 10 & Busyness status & 1.756 & 0.516 & 2.389 & 0.416 & 0.485 & 0.236 \\
\hline 11 & Social support. & 2.400 & 0.236 & 2.389 & 0.416 & 4.908 & 0.009 \\
\hline
\end{tabular}

There was a statistically significant difference if $* \mathrm{P}<0.05$ 
The results of the Chi-Square test regarding the relationship between compliance and variables that influence it can be seen in table 3 , all variables, such as family support, drug side effects, treatment costs, the role of health workers, therapeutic beliefs, knowledge of therapeutic effects, providing drug information, motivation for treatment, affordability of health services, busyness status, and social support have an effect on compliance. The ones that have a statistically significant effect are the variables motivation for treatment. Variable Motivation for treatment is quite high, reaching $84 \%$ (table 2). The test results show a significant relationship with a study conducted by Sari (2019) on pulmonary TB patients showing that motivation for treatment has a significant relationship with compliance [17]. Research conducted by Varming (2015), also shows that motivation for treatment is very influential on compliance to medication [18]. The results of research conducted by Nuratiqa, N, (2020) on hypertensive patients also shows motivation to seek treatment is significantly related to compliance $[19,20]$.

The variables drug side effects, the role of health workers, social support, therapy beliefs, knowledge of therapeutic effects gave a significant difference even if only in one city. Similar conclusions were also obtained by researcher Nurhanani (2020) who carried out hypertension patients in Semarang City, namely that compliance to taking medication was significantly related to busy work status, knowledge of how to take medicine and social support [21]; conclusions also obtained by Rasajati researchers (2015), compliance to taking medication was significantly related to distance from the house to health services, level of knowledge about hypertension management, motivation treatment, and family support [22]. Khan (2014) also stated that there are four main factors that cause non-compliance to taking medication in hypertensive patients, namely the emergence of "drug side effects", "forgetfulness", "busyness status" and "the inconvenience of taking medication when outside the home" [23].

\section{CONCLUSION}

In general, the research objects in three cities in Indonesia have good and very good levels of compliance in taking medication. Compliance in taking medication is significantly influenced by treatment motivation.

\section{ACKNOWLEDGMENT}

The author would like to thank those who helped this research, the regional governments of Bengkulu, Banjarmasin, and Yogyakarta City, as well as the Ahmad Dahlan University Yogyakarta Research Department, patients as the objects of this research and pharmacist colleagues who helped a lot in this report.

\section{FUNDING}

No competing financial interests exist.

\section{AUTHORS CONTRIBUTIONS}

The first author of this study made research designs, controlled data collection, processed data, compiled reports, and presented reports. The second, third, and fourth authors are responsible for data collection, and the fifth author is responsible for data processing.

\section{CONFLICT OF INTERESTS}

All authors have no conflict of interest with any party.

\section{REFERENCES}

1. Osamor PE, Owumi BE. Factors associated with treatment compliance in hypertension in southwest Nigeria. J Health Popul Nutr 2011;29:619-28.

2. Goodman and Gilman's. The pharmacological basis of therapeutics. Thirteenth Edition. USA: McGraw-Hill Education; 2018.
3. Tackling G, Borhade MB. Hypertensive heart disease. In: StatPearls. Treasure Island (FL): StatPearls Publishing; 2020.

4. Pugh D, Gallacher PJ, Dhaun N. Management of hypertension in chronic kidney disease. Drugs 2019;79:365-79.

5. Sinha AD, Agarwal R. Clinical pharmacology of antihypertensive therapy for the treatment of hypertension in CKD. Clin J Am Soc Nephrol 2019;14:757-64.

6. Brunström M, Carlberg B. Effect of antihypertensive treatment at different blood pressure levels in patients with diabetes mellitus: systematic review and meta-analyses. $\mathrm{Br}$ Med J 2016:352;i717.

7. Muhlis M, Prameswari A. Kepatuhan penggunaan obat pada pasien hipertensi di Instalasi Rawat Jalan Salah Satu RSUD di wilayah Daerah Istimewa Yogyakarta. Jurnal Insan Farmasi Indonesia 2020;3:104-13.

8. Gupta R, Guptha S. Strategies for initial management of hypertension. Indian J Med Res 2010;132:531-42.

9. Sinuraya RK, Destiani DP, Puspitasari IM, Diantini A. Pengukuran tingkat kepatuhan pengobatan pasien hipertensi di Fasilitas Kesehatan Tingkat Pertama di Kota Bandung. Indones J Clin Pharm 2018;7:124-33.

10. Dharan DR, Molly KT. Factors influencing compliance to therapeutic regimen among patients with hypertension. Asian J Pharm Clin Res 2017;10:286-9.

11. Mahmoud MIH. Compliance with the treatment of patients with hypertension in almadinah almunawwarah: a communitybased study. J Taibah University Med Sci 2012;7:92-8.

12. Chusna N, Puspitasari I, Probosuseno P. Pengaruh kepatuhan dan pola pengobatan terhadap hasil terapi pasien hipertensi. J Management Pharm Pract 2014;4:230-5.

13. Rahmadani MA, Sari A. Kepatuhan terhadap pengobatan pada pasien hipertensi dengan komplikasi diabetes melitus di Puskesmas Yogyakarta. Media Farmasi 2018;15:1-5.

14. DiPiro JT, Spruill WJ, Wade WE, Blouin RA, Pruemer JM. Concepts in clinical pharmacokinetics. $5^{\text {th }}$ Ed. Ohio: American Society of Health-System Pharmacists; 2010.

15. Lacy CF, Armstrong LL, Goldman MP, Lance LL. Drug information handbook. Ohio: Lexi-Comp Inc; 2007.

16. Jamaludin AN. Sosiologi perkotaan: memahami masyarakat kota dan problematikanya. Bandung: Penerbit CV Pustaka Setia; 2015.

17. Sari LT. Hubungan motivasi kesembuhan dengan kepatuhan minum obat pada penderita TB paru dewasa. JuKe 2019;3:1-8.

18. Hasan M. Hubungan motivasi kesembuhan dengan kepatuhan minum obat penderita tuberkulosis paru di puskesmas jambe kabupaten tangerang. J Penelitian Pengabdian Masy 2019;2:1-10.

19. Nuratiqa N, Risnah R, Hafid MA, Paharani A, Irwan M. Faktor yang berhubungan dengan kepatuhan minum obat anti hipertensi. BIMIKI 2020;8:1-10.

20. Varming AR, Hansen UM, Andresdottir G, Husted GR, Willaing I. Empowerment, motivation, and medical adherence (EMMA): the feasibility of a program for patient-centered consultations to support medication adherence and blood glucose control in adults with type 2 diabetes. Patient Prefer Adheren 2015;9:1243-53.

21. Nurhanani R, Susanto HS, Udiyono A. Hubungan faktor pengetahuan dengan tingkat kepatuhan minum obat antihipertensi (Studi pada pasien hipertensi essential di wilayah kerja Puskesmas Bandarharjo Kota Semarang). J Kes Masy 2020;8:114-21.

22. Rasajati Q, Raharjo B, Ningrum DN. Faktor-faktor yang berhubungan dengan kepatuhan pengobatan pada penderita hipertensi di wilayah kerja Puskesmas Kedungmundu Kota Semarang. Unnes J Pub Health 2015;4:16-23.

23. Khan MU, Shah S, Hameed T. Barriers to and determinants of medication adherence among hypertensive patients attended National Health Service Hospital, Sunderland. J Pharm Bioallied Sci 2014;6:104-8. 